DOI https://doi.org/10.18551/rjoas.2017-05.13

\title{
REDEVELOPING COMPETITIVE ADVANTAGE OF RATTAN SMES CLUSTER IN CIREBON
}

\author{
Asngadi* \\ Tadulako University, Indonesia \\ Surachman, Indrawati Nur Khusniyah, Sumiati \\ Faculty of Economics and Business, University of Brawijaya, Indonesia \\ *E-mail: asngady@yahoo.com
}

\begin{abstract}
Rattan SMEs Cluster in Cirebon is the national icon of rattan furniture industry even though raw materials needed for the industry do not source locally. The level of production reached $80 \%$ of the national production of rattan furniture. Rattan furniture industry in Cirebon has been going up and down for the past decades. The purpose of the study was to analyze obstacles and altenative policy needed to re-develop competitive advantage of the rattan furniture industry after the Memorandum of Understanding between 3 Ministers, the Minister of Trading, Minister of Forestry and Minister of Industry, that banned raw rattan export was issued in 2011. The design of the study was mix method. Qualitatively, the findings of the study were some obstacles the SMEs encountered in developing competitive advantage of the rattan furniture industry in Cirebon. The obstacles were related to the market, raw materials, employment, capital and regulation. As an addition, there were 15 alternative policies the local stakeholders may do to develop competitive advantage of the rattan furniture SMEs in Cirebon. Based on AHP (Hierarchical Process Analysis), quantitatively, the finding revealed that raw material should become the highest priority to ensure the rattan furniture SMEs in Cirebon got constant supply of the raw materials they needed. The percentage was $38 \%$. On the other hand, the percentage of regulation and marketing was $10 \%$ each. At the policy alternatives level, efforts to encourage the consistency of banned raw materials exports rank first among all policy alternatives, which reaches $16 \%$. In terms of alternative policy, the most important alternative policy was the one that encouraged raw rattan export ban. The percentage was $16 \%$.
\end{abstract}

\section{KEY WORDS}

Rattan, cluster, SMEs, competitive advantage.

Rattan is one of the national commodities. $80 \%$ rattan used in the industry was grown in Indonesian rain forest. Therefore, the government encourages establishment of furniture industry of which raw material is either rattan or timber. Currently, rattan SMEs clusters have grown rapidly in several areas such as Solo, Sidoarjo, Malang and Cirebon.

At present, Cirebon is the largest rattan producer in Indonesia since the area produces $80 \%$ of the national rattan products. $80 \%$ of the rattan SMEs in Cirebon export their products (FT Link Consultant - SHK Kaltim, Mei, 2005). Rattan industry in Cirebon started growing in 1970s although the raw material do not source locally (Sriwarno and Iman, 2009). Table 1 describes type of raw materials the rattan SMEs used and where they are from.

Tabel 1 reiterates that the raw materials used in the rattan SMEs in Cirebon came from other regions. It is evident that Cirebon is able to develop a product despite the fact that the raw materials for the industry should be shipped from other areas and makes the industry its local competitive advantage. The rattan SMEs in Cirebon does not consider absence of the raw materials as obstacle in developing the competitive advantage of the industry.

Since 2011, due to its massive growth, the rattan furniture industry in Cirebon has become a commodity in Kompetensi Inti Industri Daerah (KIID) (Department of Industry of 
Cirebon, 2014). There were 1,331 rattan furniture SMEs in the area in 2013 (Department of Industry of Cirebon, 2014).

Table 1 - Region Where the Raw Materials for the Rattan Industry in Cirebon are Obtained

\begin{tabular}{|c|c|c|c|}
\hline No & Raw Material & Utility & Region where the Raw Materials are Obtained \\
\hline 1 & Manau & Frame & Sulawesi \\
\hline 2 & Semambu & Frame & Sulawesi \\
\hline 3 & Tohiti & Frame & Kalimantan, Sumatera \\
\hline 4 & Kubu & Rattan Woven & Kalimantan \\
\hline 5 & Jawit & Rattan Woven & Kalimantan, Sumatera \\
\hline 6 & Lacak & Rattan Woven & Aceh \\
\hline 7 & Slimit & Rattan Woven & Kalimantan, Sulawesi \\
\hline 8 & Sarang Buaya & Rattan Woven & Kalimantan, Sumatera, Java \\
\hline 9 & CL & Rattan Woven & \\
\hline
\end{tabular}

Source: Department of Industry and Trading of Cirebon, 2014.

Although rattan furniture is one of the leading industry in Indonesia, it faces several issues especially when the government issued some policies related to rattan export. The government is unable to maintain consistent supply of raw materials for the rattan SMEs in Cirebon. During its peak, the SMEs exported 3,000 containers of rattan furniture each month but the number plummeted to 1,200 containers per month (Department of Industry of Cirebon, 2015). Besides decreasing amount of export, the policy related to raw material export had killed half of the rattan SMEs in Cirebon. There were 600 SMEs exporting rattan furniture, but now, the number declines to 280 (AMKRI of Cirebon, 2016).

Sharp decline the rattan SMEs in Cirebon creates public awareness that the national rattan industry is struggling. The national rattan industry can no longer compete with the rattan industry from China and Vietnam because of raw material export. China and Vietnam cannot produce their own rattan as the raw material for their rattan industries (AMKRI of Cirebon, 2016). The awareness has reached a turning point since the issuance of the government regulation on raw rattan export ban.

Table 2 - Growth of Rattan Industry in Cirebon between 2006 and 2013

\begin{tabular}{|c|c|c|c|}
\hline No & Tahun & Number of SMEs & Number of Employee \\
\hline 1 & 2007 & 1,149 & 64,898 \\
\hline 2 & 2008 & 1,160 & 65,519 \\
\hline 3 & 2009 & 1,172 & 52,414 \\
\hline 4 & 2010 & 1,224 & 54,184 \\
\hline 5 & 2011 & 1,260 & 54,291 \\
\hline 6 & 2012 & 1,298 & 55,011 \\
\hline 7 & 2013 & 1,331 & 55,654 \\
\hline
\end{tabular}

Source: Department of Industry and Trading of Cirebon, 2014.

Table 2 shows that the rattan industry in Cirebon reaches its lowest poin in 2009. Although exporting raw rattan was prohibited in 2011, the national rattan industry has yet been recovered completely. The 2013 data show that employment rate in the year is lower than 2008, when employment rate is 65,519. Despite of the increasing trend in the national rattan industry, the stakeholders should develop some programs to improve competitive advantage of the rattan SMEs in Cirebon.

As the effect, strategic design is needed in order to develop competitive advantage of the rattan SMEs in Cirebon in a long term after the prohibition of raw material export. In general, the objecvtive of the study is to analyze some strategies the stakeholders design in order to improve competitive advantage of the rattan SMEs in Cirebon after the issueance of the Memorandum of Understanding between three Ministers in 2011 that ban the export of raw materials.

From the explanation above, several problems can be made as follows: 
- What obstacles the rattan SMEs in Cirebon encounter in developing their competitive advantage after the raw material export ban?

- What alternative policy facilitating the development of the competitive advantage of the rattan SMEs in Cirebon?

\section{LITERATURE REVIEW}

In Indonesian context, SME, which provides a lot of job vacancies, is survivalist in nature (Kuncoro, 2016). At the same time, there are abunandt SMEs in Indonesia. Such condition creates competitive business atmosphere and as the consequence, SMEs should keep on making breakthrough and developing new concept. One of the concepts to develop SMEs effectively is cluster-based one (Mawardi, 2009). Theoretically, the concept was developed by Marshal (1920) using geographical economy as the reference. Not only did cluster gather several industries geographically located close to each other, but it also referred to a group of companies and organizations that were related to each other (communality) and complemented each other (compementary) (Porter, 1998).

Therefore, cluster consists of various related entities. There are at least three entities in a cluster namely, company, supporting institution, and the government (Alyward,2006, Eisebetd and Eisebeth,2005; Sonobe and Otsuka, 2006). Besides that, one requirement for developing cluster is joint action as an effort to develop together where both small and large industries become the supporting institutions (Maridjan, 2005). Employing the concept of cluster in developing SMEs brings the following advantages, for instance1) cluster strengthens local economics; 2) it strengthens industrial reorganization; 3) it enhances networking between companies; 4) it allows public resources emphasis, 5) it improves productivity and efficiency and 6) it encourages innovation.

Good cluster should be able to realize joint action that triggers social capital as form of interaction between small and large companies, including SMEs within the cluster (Maridjan, 2005). A pretty comprehensive approach to develop cluster is called Diamond Model (Porter, 1990). Focus of the Diamond Model is that competitive advantage of a cluster is determined by four variables, namely input, supporting and related industry, demand, competitive strategy, in which competitive advantage of the cluster itself and increase in local economics become the final outcome. Input involves natural resources, human resource, information technology. Supporting and related industry involves networking, association and access to funding. Demand involves strenghtening local and international market including product quality. Finally, competitive strategy involves export strategy for global market and regulation that encourages investment to increase productivity (Porter,1990).

An attempt to develop competitive cluster should begin with mapping for development of the cluster and be followed by involvement of government policy that encourages artisanal growth into dynamic cluster. The strengthening initiation should represent top down-mixedbottom up (Mawardi, 2009).

Based on the elaboration, it is obvious that an attempt to develop cluster should take elements that develop competitive advantage into account. Besides that, the development should be able to develop artisanal cluster into dynamic one.

\section{METHODS OF RESEARCH}

Mix method with sequential mixed method strategy was conducted to solve the problems stated above (Cresswel, (2013).

At the first stage, the study was a qualitative study where the researchers conducted in-depth interview and the business association, government and rattan community in Cirebon became the key informants. The findings were specific themes describing several issues the rattan SME clusters encountered after raw rattan export was banned.

At the second stage, the study was a quantitative study where AHP (Hierarchical Process Analysis) was conducted to identify degree of the issues obtained based on the 
qualitative analysis. In addition, the AHP was conducted to describe importance of the alternative policies designed to overcome the issues. The AHP analysis was as follow:

Level 1:

Objective

Level 2:

Criteria

Level 3:

Alternative Policy

\section{Redeveloping Competitive Advantage}

of Rattan SME Clusters

in Cirebon

Description:

A. Raw Material Export Ban Continuity;

B. SME-Bank Facility

Improving the Government Program in the form of training

Promoting Local Market by establishment of "kampung wisata rotan," a tourist attraction where visitors can visit the rattan industry;

Bisnis matching and customer education;

Promoting Eco-friendly Industry;

Market intelligence training for the industry;

Government-industry collaboration for job training

Strengthening Rattan Cultivation Program;

Direct buying from the farmer to the industry;

Developing scheme for rattan trading between regions

Threading as the Local Content for Senior High School Students,

Strengthening warehouse receipts for credit guarantees;

Synchronization between the regional government regulations and the governor regulation;

Establishment of Rattan Industry.

Figure 1 - AHP Analysis

\section{RESULTS OF RESEARCH}

Based on the result of the AHP after comparing the criteria, and alternative policy needed to develop competitive advantage of the rattan SME clusters in Cirebon, the findings were as follow:

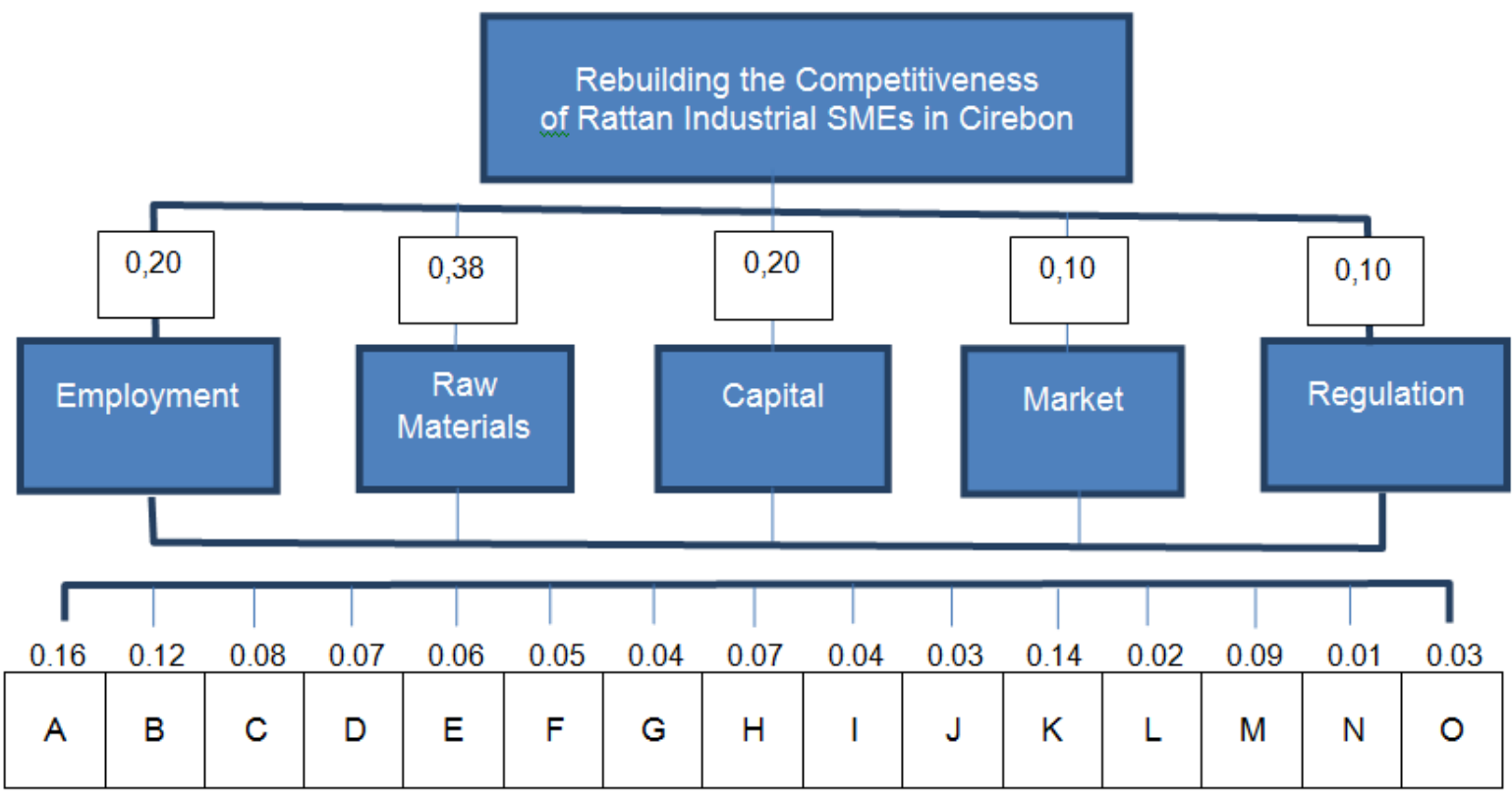

Figure 2 - Findings of study 
The chart showed scores of every criteria describing the difficulties in developing the rattan SME clusters in Cirebon. It also showed scores of each alternative policy that could potentially solve the difficulties. Table 3 described degree of importance of the alternative policies. The degree of importance was as follow:

Table 3 - Degree of Importance

\begin{tabular}{|l|l|l|}
\hline \multicolumn{1}{|c|}{ Aspect } & \multicolumn{1}{c|}{ Score } & Ranking/Priority \\
\hline Market & 0.10 & 4 \\
\hline Raw Material & 0.38 & 1 \\
\hline Employment & 0.20 & 3 \\
\hline Capital & 0.23 & 2 \\
\hline Regulation & 0.10 & 5 \\
\hline
\end{tabular}

Based on the table, raw material is the most important aspect to consider to develop the rattan SME clusters in Cirebon. The second aspect to consider was capital. The challenge the rattan employers encounter was to get capital. At last, the third aspect to pay attention to was skilled employees.

Based on the alternative policy to solve the issues the rattan SME clusters in Cirebon encountered, the result of the AHP analysis was as follow:

Table 4 - Degree of the Alternative Policy for Developing SME Cluster in Cirebon

\begin{tabular}{|l|c|c|}
\hline \multicolumn{1}{|c|}{ Alternative Policy } & Score & Rank \\
\hline Raw Material Export Ban Continuity & 0.16 & 1 \\
\hline SME-Bank Facility & 0.12 & 3 \\
\hline Improving the Government Program in the form of training & 0.08 & 5 \\
\hline $\begin{array}{l}\text { Promoting Local Market by establishment of "kampung wisata rotan," a tourist attraction where } \\
\text { visitors can visit the rattan industry }\end{array}$ & 0.07 & 7 \\
\hline Bisnis matching and customer education & 0.06 & 8 \\
\hline Promoting Eco-friendly Industry & 0.05 & 9 \\
\hline Market intelligence training for the industry & 0.04 & 11 \\
\hline Government-industry collaboration for job training & 0.07 & 6 \\
\hline Strengthening Rattan Cultivation Program & 0.04 & 10 \\
\hline Direct buying from the farmer to the industry & 0.03 & 12 \\
\hline Developing scheme for rattan trading between regions & 0.14 & 2 \\
\hline Threading as the Local Content for Senior High School Students & 0.02 & 14 \\
\hline Strengthening warehouse receipts for credit guarantees & 0.09 & 4 \\
\hline Synchronization between the regional government regulations and the governor regulation & 0.01 & 15 \\
\hline Establishment of Rattan Industry & 0.03 & 13 \\
\hline
\end{tabular}

Table 4 described 15 alternative policies that were able to solve the problems the rattan SMEs in Cirebon encountered. Each of them had different degree of importance as well as contribution. The higher ranking an alternative policy had, the more important it was to consider in redeveloping the competitive advantage of the rattan SME cluster in Cirebon.

\section{DISCUSSION OF RESULTS}

Based on AHP analysis, continuous supply of raw materials was the most critical aspect in redeveloping the competitive advantage of the rattan SMEs. It was urgent to develop supply chain as soon as possible because Cirebon could not supply raw material for the rattan industry despite the fact that the area was one of the leading rattan industries in Indonesia (as seen in Table 1). The government policy that ban export of raw material needed by rattan industry caused lack of raw material for the national rattan industry (AMKRI, 2015). On the other hand, raw material was vital element to develop competitive advantage of the industry (Hongqiang, 2012). Raw materials had the largest contribution to industrial viability. Supply of raw materials will cause domino effect. In an industry in which raw materials became one of the issues to encounter, the supply of raw materials from different regions had a central message in supporting industrial sustanability (Sriwarno and 
Imam, 2009). The same condition occurred in Malaysia. China considered Malaysia the major competitor as mahogany furniture manufacturer ever since the export of raw material for the industry was prohibited (Hongqiang, 2012).

The information provided a justification that the raw material guaranteed the sustainability of the rattan SMEs in Cirebon. There were several alternative strategies with different degree of importance that may be conducted. The policy with the highest priority was for the government to ban export of the raw material. It ranked first among the 15 alternative policies that were able to develop the competitive advantage of the rattan SMEs in Cirebon. There were also some urgent alternatives policies to ensure consistent and sufficient supply of the raw material in the long term; the alternative policies were strengthening the chain of raw material supply between regions to shorten the length of the supply chain, facilitating direct purchase between the rattan farmers and the rattan industry, strengthening rattan cultivation and establishing regional rattan cooperatives.

The stakeholders in Cirebon should pay attention to the effort to develop and strengthen the supply chain of the raw materials. Strong supply chain of raw materials will facilitate input that supported the competitive advantage of the cluster (Porter, 1990). Empirically, the study mentioned several strategies that revealed the vital role of raw material supply chain. The continuity of the raw material export ban was at the first rank and developing scheme for rattan trading between regions was at the second rank. Both of the policies seemed politically related and therefore, consistent contribution of both central and local government was needed to develop the competitive advantage of the SMEs cluster (Porter,1990). Besides the policy that prohibited the export of the raw material, another important strategic alternative to strengthen the supply chain of the raw material in the long run was rattan cultivation. Goal of the rattan cultivation was to accelerate regeneration of rattan and prevent excessive exploitation of the forest.

Another important aspect to redevelop the success of the rattan SMEs in Cirebon was capital. Empirically, the export of the raw material for the rattan industry decreased the competitive advantage of the rattan SMEs in Cirebon, and eventually the SMEs tended to be not bankable because the competitive advantage of Cirebon furniture products overseas was relatively low. As the result, the performance of the SMEs was also getting weaker. Unfortunately, banks were beginning to avoid rattan industry as the choice of bank marking. When the export of raw materials closed in 2011, the banks were still waiting and seeing the activities of the rattan industry before making decision whether or not the rattan industry deserved to get loan from them. It was a challenge for the growth of the SME clusters. Therefore, the degree of importance of the marking became really important and was ranked second.

Giving loan for SMEs in order to increase their capacity accelerated the growth of the SMEs. However, it sometimes was difficult for the SMEs to get access. Therefore, macro policies were needed to encourage more SMEs to grow in a cluster. It reflected the fact that the government' policy related to SMEs tend to be based on insufficient policy in cluster development so that the real role of government should be greater (Porter, 1998). As a problem frequently encountered by SMEs, the financial issues must be solved with a tangible approach. Low cost financing schemes were required for SMEs besides other technical aspects (Lundequist and Power, 2002).

Based on the data, Bank Exim provided some loan for the SMEs, especially the ones of which orientation was export. Therefore, developing network between SMEs and banks were vital. The evidence was that networking between bank and SME ranked third in the result of the AHP analysis. The upstream industry should be involved in getting access to SME financing so that the government role in strengthening warehouse receipts for credit guarantees could be implemented. Thus, the downstream industries and related industries collaborated with the support of adequate access to finance (Porter, 1990).

Employment was the real issue encountered by the rattan SME clusters in Cirebon. Customers had shifted to Chinese and Vietnamese-made rattan furniture since the export of raw materials began. Worse, the rattan SMEs employees quit their job and had another job or work for the Vietnamese rattan industry $(A M K R I, 2015)$. When the government banned the 
export of the raw material, the skilled employees had had other job. They were reluctant to return to their job at the rattan industries despite of the increasing demand of the rattan furniture made by the national SMEs. As the consequence, the stakeholders should race against the time to train local employees to meet the market demand. Therefore, training, the one conducted by the SMEs themselves or the one sponsored by the government, was pivotal. Training ranked $5^{\text {th }}$ and $6^{\text {th }}$ in the AHP analysis. Such condition reiterated the importance of input or skilled employees in this context to develop successful and sustainable cluster (Porter, 1990). As one part of the programs of which purpose was to strengthen the rattan industry, training should be conducted continuously in the long run (Sriwarno and Imam, 2009). Besides that, in order to have sustainable rattan industry, the industry (private institution) should have collaboration with the government due to the government limitation in marking (Mawardi, 2009). The training conducted by both the government and the industry indicated the increasing role of the industry. Government training lasted for 26 working days and was followed by internship; the internship would stop when an employee had become a qualified one. Another alternative to get skilled employees for the rattan industry was integration of the skill (threading) as local content for senior high school students.

The shift from the national product to one made in China and Vietnam took place when the government allowed the export of the raw material. Another factor contributed to the success of the rattan industry in the countries was human resources/ employment.

Once the export of the raw material had been banned in 2011, less amount of rattan furniture from China and Vietnam was displayed in international furniture exhibition (Amkri, 2015). It showed that the market had shifted to rattan furniture made in Cirebon. Table 5 showed that the amount of the rattan furniture made in Cirebon getting exported has increased since 2012.

Table 5 - Rattan Furniture Export Rate in Cirebon in 2010-2013

\begin{tabular}{|c|c|}
\hline Year & Export Rate (Rupiah) \\
\hline 2010 & $1,392,112,174$ \\
\hline 2011 & $1,514,244,781$ \\
\hline 2012 & $1,676,132,887$ \\
\hline 2013 & $1,876,554,120$ \\
\hline
\end{tabular}

Source: Department of Industry and Trading of Cirebon, 2015.

Table 5 justified that putting a halt of the export of the raw material in 2011 increased the amount of exported local furniture. In other words, the ban increased the competitive advantage of the rattan furniture produced by the SME cluster in Cirebon and showed that the national product had won against their two main competitors, China and Vietnam (Amkri, 2015). The reality justified Porter (1990)'s diamond concept that the market affected competitive advantage of a cluster. The importance of the market reminded the government to issue a policy where development of SME clusters became the orientation; the government should issue policy related to technical assistance and both national and international marketing service (Hill, 2001). The rattan SMEs from Cirebon success to penetrate to the international market would accelerate the development of the rattan industry in Cirebon. The establishment of rattan tourism village as a forum to increase the love of rattan products was a suitable alternative to develop the national rattan furniture market. In addition, promoting eco-friendly product was a good alternative amid the demands of environmentally friendly products in Europe and America (PUPUK, 2013). Competition between rattan products with other substitution products required market intelligence from the rattan SMEs in Cirebon. More knowledge about the market the SMEs had, the better competence they had to implement the marketing strategy they had especially the one to be implemented in foreign countries.

Support from the government in the form of policy was needed to develop the competitive advantage of the SME clusters. In this context, government contribution gave a strong nuance in the development of SME cluster in Cirebon. Different level of the 
government (local and provincial) on the research site frequently led to overlapping. The establishment of the Technical Implementation Unit for the rattan industry in the area by the government of West Java was improving the cluster, but at the same time, a synergy between the Technical Implementation Unit and the local government was needed because some of the related policies had yet been evaluated optimumly. Thus, in the context of the cluster context, although policies had been issued, their effectiveness still requires strengthening and synchronization between the various programs (Sato, 2000, Bery et al, 2002). Inter-institutional alignment in designing cluster strengthening programs required considerable coordination, as this problem in reality led to the inefficiency of cluster development in Indonesia in general (Porter, 1999).

\section{CONCLUSION}

As SME clusters of which raw material does not source in or around Cirebon, the growth of the cluster is pretty dynamic. The biggest challenge is the supply of raw material in the long-term. Lack of supply will affect the overall competitive advantage of the cluster.

Effort to redevelop the competitive advantage of the rattan SMEs in Cirebon should begin with analysis of the main obstacles and deciding alternative solutions using mix methods. The study reveals the degree of importance of each of the attributes that develop the competitive advantage of the rattan SME clusters in Cirebon. The aspect with the highest degree of importance is raw materials, followed by capital, employment, marketing and regulation.

\section{REFERENCES}

1. Alyward, DK \& Glynn,J, 2006, SME Innovation Within Australian Wine Industry: A Cluster Analysys, Small Enterprises Research. The Journal Of The AMAANZ (Small Enterprises Association Of Australia And New Zealan) Vol.14. Pp 1-16.

2. Amkri, 2015, Roadmap industri mebel and kerajinan Indonesia: Target Mencapai 5 Milyard USD, AMKRI

3. Berry, A., Rodriques E \& Sande, H, 2002, Firm And Group Dynamic In The Small And Medium Enterprise Sector In Indonesia, Small Business Economics, vol.18,pp 141-161

4. Hill, H. (2001). Small Medium Enterprises in Indonesia, Asian Survey, 41 (2) ; 248-270

5. Hongqiang, Yang; Ji Chunyi; Nie Ying; Hong Yinxing, 2012, China's Wood Furnituremanufacturing Industry: Industrial cluster And Export Competitiveness, Forest Products Society 2012. Forest Prod. J. 62(3):214-221

6. kpshk.org/wp-content// 2005, Laporan-Akhir: Survey Perdagangan Rotan Nasional. www. kpshk.org di akses 1 Juni 2015.

7. Lundequist,P \& Power D, 2002, Putting Porter into practise? Practise of regional cluster building: evident from sweeden, European Planning Studies, vol.10,pp.685-704.

8. Mawardi, Mukhammad Kholid; Choi, Ty; Perera, Nelson. 2011, The Factors of SME Cluster Developments in a Developing Country: the case of Indonesian clusters, Conference Proceedings; Washington: 1-28. Washington: International Council for Small Business (ICSB). (2011)

9. Porter, M E, 1990, The Competitive Anvantage Of Nation, Free Press, New York.

10. Porter,M E, 1999, Improving Indonesian Competitiveness. Paper presented to Susilo Bambang Yudhoyono, Jakarta.

11. Pupuk, 2013, Base Line Survey Report: Prospect Indonesia, PUPUK

12. Sato, Y. 2000, Linkage formation by small firm: the case of rural cluster in Indonesia, Bulletin of Indonesian Economic Studies, Vol 36, pp 137-166.

13. Sriwarno, Andar Bagus \& Imam Damar Djati, 2009, Enhancing Local Designers Skill in Rattan Furniturlndustries in Cirebon through Comprehensive-Design Approach Regarding Buyers' Dependencies Prevention. ITB J. Vis. Art \& Des., Vol. 3, No. 2, 175186 